when suddenly $\mathrm{Dr}$ Rosario came into the room. She was a delightful, jolly woman with a reassuring smile; and she spoke excellent English with a slight but charming accent. She ushered Hilda and me into her consulting room and offered us a seat on comfortable armchairs. All this luxury was making me a little uneasy about how much this was going to cost us. But we were carrying Hot-Air Comprehensive travel insurance, a precaution on which I insisted, not wanting to be mired in EU bureaucracy and form-filling etcetera, although we do have those little plastic cards. Dr Rosario listened carefully to my symptoms and gave me a thorough examination. Her calming presence reminded me a little of Dr Brenda and the inflammation of my pancreas (or liver) was already beginning to subside under her gentle touch. I mentioned that I had been constipated (or constipado) as I put it, trying to meet her halfway in the matter of language. I am told that foreigners always appreciate it if you have a try. Dr Rosario looked rather puzzled and suggested some nose drops, until Victoria explained that 'constipado' in Spanish means 'a cold'. I decided to conduct the rest of the consultation in English.

When I was dressed again, Dr Rosario sat at her desk and wrote out a large number of prescriptions, one item on each sheet. They are obviously much more generous when it comes to prescribing than their English counterparts who seem to grudge you every spoonful of cough linctus as though it was vintage champagne. We said a cordial goodbye to the doctor while Victoria attended to the paperwork with her secretary. She said she would add the bill to our Hot-Air Account so that we could easily claim it back on the insurance. Then we went to the nearest Farmacia for my prescriptions. I was glad to see that they included a mild laxative, an antispasmodic, an enzyme preparation to aid the digestion, some excellent vitamin supplements and a week's supply of Spanish Amoxicillin. As we took our seats in the Katarina's Tapas bar and ordered our Sangria I felt I could look forward to trouble-free health for the rest of the weekend. Hilda was not so certain, but she does worry about me a good deal and I think the relaxation will do her good.

We are grateful to John Salinsky for these extracts from Norman Gland's diary.

DOI: 10.3399/bjgp08X319837

\title{
Professor Jan Van Es
}

Jan Van Es died on 28 June 2008 at the age of 86 . In 1966 he was the first GP in the Netherlands to be appointed to a university professorship. He held a newly created chair in the University of Utrecht, at first combining this with his practice at Apeldoorn and later, with editing a medical journal.

I first met him in 1972 at Leeuwenhorst, near Haarlem, at a conference centre in the middle of the Dutch bulbfields, in full bloom. The conference proved to be important because it led immediately to the formation of the Leeuwenhorst European Study Group. Representatives from 11 European countries (from both sides of the 'iron curtain') agreed on a European definition of the role of the GP in healthcare. This became widely accepted as a basis for creating specific early postgraduate training programmes for future practitioners.

Jan followed Patrick Byrne as chairman of this group and I was secretary to them both. The group continued to meet twice yearly for the next 7 years in different member countries before handing over its important role to a younger group representing 21 countries.

For me, Jan was an especially close friend over 36 years. We talked by telephone every week during the 2 years of his final illness.

He had the gift of always making other people feel valued. I have known very few other colleagues who have been such good listeners or so good at drawing out contributions from a large audience in a lecture theatre.

Jan chose to be an associate of our College in 1963. In 1967, the College presented him with its honorary fellowship. The Dutch government honoured him with a knighthood in 1982. I cannot believe that he is no longer there to talk to.

\section{John Horder}

DOI: 10.3399/bjgp08X319846

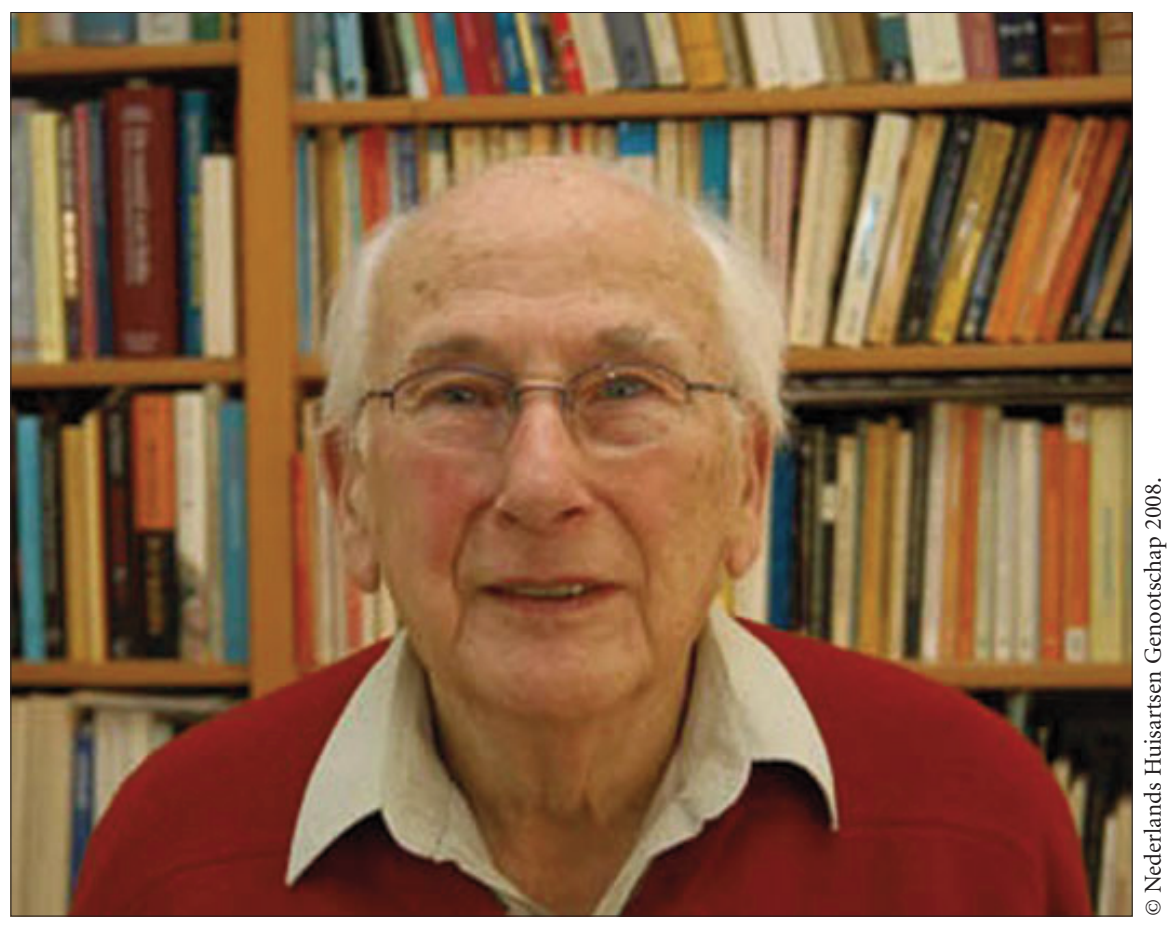

